\title{
Analisis QR, DER dan NPM terhadap Harga Saham Perusahaan Food and Beverages di Indonesia
}

\author{
Diana Irsanti Haloho \\ Universitas Prima Indonesia \\ dianairsanti.haloho@gmail.com \\ Saprina Perangin Angin \\ Universitas Prima Indonesia \\ saprinaperangin82@gmail.com \\ Sendi Paulina Malau \\ Universitas Prima Indonesia \\ sendipaulinamalau@gmail.com
}

\begin{abstract}
Abstrak
Sebagai suatu instrumen investasi harga saham yang diperoleh oleh pemodal akan mengalami perubahan seiring dengan berjalannya waktu. Perubahan tersebut dipengaruhi beberapa faktor, baik eksternal maupun internal. Dari sisi eksternal, inflasi merupakan suatu standar yang dijadikan acuan bagi dunia perekonomian , termasuk dunia investasi. Dan dari sisi internal, Quick Ratio, Debt to equity Ratio dan Net Profit Margin itu sendiri memiliki pengaruh tersendiri terhadap harga saham. Objek dalam penelitian ini adalah harga saham perusahaan subsektor Food and Beverages yang terdaftar di Bursa Efek Indonesia periode 2014-2018. Penelitian ini merupakan kriteria dalam menentukan sampel yang sering disebut dengan Purposive Sampling. Penelitian ini mendapatkan 10 perusahaan emiten yang bergerak di Food ang Beverages terdaftar di BEI pada periode 2014-2018. Regresi linier berganda digunakan dalam penelitian ini untuk menjawab permasalahan pokok penelitian. Kesimpulan dari penelitian ini adalah pengaruh NPM terhadap harga saham adalah signifikan positif, sedangkan pengaruh QR, DER terhadap harga saham adalah signifikan negatif pada perusahaan Food and Beverages yang terdaftar di BEI pada periode 2014-2018. Ketiga variabel independen yang digunakan pada penelitian ini QR, DER dan NPM bersama-sama berpengaruh signifikan bagi harga saham perusahaan di bidang Food and Beverages yang terdaftar di BEI periode 2014-2018.
\end{abstract}

Kata Kunci Quick Ratio (QR), Debt to Equity Ratio (DER), Net Profit Margin (NPM), Harga Saham

\section{PENDAHULUAN}

\subsection{Latar Belakang}

Pasar modal memiliki peran besar bagi perekonomian suatu negara karena pasar modal memiliki dua fungsi sekaligus, yaitu fungsi ekonomi dan fungsi keuangan. Pasar modal dikatakan memiliki fungsi ekonomi karena menyediakan fasilitas atau wahana yang mempertemukan dua kepentingan, yaitu pihak yang memiliki kelebihan dana (investor) dan pihak yang memerlukan dana (issuer). Keberadaan pasar modal membuat para investor dapat mengambil keputusan investasi dengan lebih rasional dan masyarakat memiliki kesempatan yang luas untuk melakukan diversifikasi investasi yang dianggap paling menguntungkan. Perusahaan Food and Beverages dipilih karena memegang peranan penting dalam memenuhi kebutuhan konsumen. Didasarkan pada kenyataan tersebut, perusahaan makanan dan minuman dianggap akan terus survive. Industri makanan dan minuman adalah industri yang perkembangannya baik, pertumbuhan yang positif, sangat cepat dan akan selalu ada karena merupakan salah satu kebutuhan pokok. Industri makanan, minuman, dan tembakau masih menjadi cabang yang memberikan kontribusi terbesar terhadap pertumbuhan industri nasional.

Perusahaan yang baik biasanya memiliki laba yang besar dan diikuti dengan harga saham yang tinggi juga. Saham merupakan surat berharga yang memberikan peluang keuntungan tinggi. Saham memungkinkan investor untuk mendapatkan return atau keuntungan (capital gain) dalam jumlah besar dalam waktu singkat. Jika harga saham suatu perusahaan selalu mengalami kenaikan maka investor atau 
calon investor menilai bahwa perusahaan tersebut berhasil dalam mengolah usahanya. Dalam hal ini, kepercayaan investor terhadap emiten atau perusahaan penerbit saham sangat dibutuhkan karena semakin banyak orang yang percaya terhadap emiten maka keinginan untuk berinvestasi pada perusahaan emiten tersebut semakin kuat mendorong kenaikan harga saham perusahaan tersebut.

\subsection{Rumusan Masalah}

Masalah yang akan ditelusuri dalam penelitian ini adalah bagaimana pengaruh setiap variabel independen penelitian secara parsial dan secara simultan berpengaruh terhadap variabel dependen (harga saham) pada perusahaan Food and Beverages yang terdaftar di Bursa Efek Indonesia Periode 2014-2018. Bagaimana pengaruh quick ratio secara parsial berpengaruh terhadap harga saham. Bagaimana pengaruh debt to equity ratio secara parsial terhadap harga saham. Bagaimana pengaruh net profit margin secara parsial terhadap harga saham. Bagaimana pengaruh quick ratio, debt to equity ratio dan net profit margin secara simultan berpengaruh terhadap harga saham.

\subsection{Tujuan Penelitian}

Tujuan dilakukannya penelitian ini adalah menguji dan menganalisis besar pengaruh setiap variabel independen penelitian secara individual dan secara simultan terhadap variabel dependen (harga saham) pada perusahaan Food and Beverages yang terdaftar di Bursa Efek Indonesia periode 2014-2018. Menguji dan menganalisis seberapa besar pengaruh quick ratio terhadap harga saham. Menguji dan menganalisis debt to equity ratio terhadap harga saham. Menguji dan menganali sis net profit margin terhadap harga saham. Menguji dan menganalisis seberapa besar secara simultan pengaruh quick ratio, debt to equity ratio dan net profit margin terhadap harga saham.

\section{LANDASAN TEORI}

\subsection{Teori Harga Saham}

Menurut Sartono (2012:41), Harga saham adalah sebesar nilai sekarang atau present value dari aliran kas yang diharapkan akan diterima. Menurut Darmadji dan Fakhruddin (2012:5), saham (stock) dapat didefenisikan sebagai tanda penyertaan atau pemilikan seseorang atau badan dalam suatu perusahaan atau perseroan terbatas. Saham berwujud selembar kertas yang menerangkan bahwa pemilik kertas tersebut adalah pemilik perusahaan yang menerbitkan surat berharga tersebut. Porsi kepemilikan ditentukan oleh seberapa besar penyertaan yang ditanamkan di perusahaan tersebut.

Berdasarkan beberapa pendapat diatas maka dapat disimpulkan bahwa saham merupakan bukti kepemilikan investor terhadap perusahaan dengan mengikut sertakan modalnya keperusahaan. Harga saham Menurut Darmadji dan Fakhruddin (2012-102), adalah Close atau Closing Price menunjukkan harga penutupan saham.

\subsection{Teori Quick Ratio (QR)}

Menurut Brigham dan Houston (2010:135), Quick Ratio merupakan rasio yang dihitung dengan mengurangi persediaan dengan aset lancar, kemudian membagi sisanya dengan kewajiban lancar.

Menurut Hani (2015:121) Faktor-faktor yang mempengaruhi likuiditas itu sendiri yakni bagian dari aktiva lancar dan kewajiban lancar, termasuk perputaran kas, dan arus kas operasi, ukuran perusahaan, kesempatan bertumbuh (growth- opportunities), keragaman arus kas operasi, rasio utang atau struktur utang.

Menurut Sujarweni (2017:61) QR dihitung dengan rumus:

$$
\mathrm{QR}=\frac{\text { Aktiva lancar }- \text { Persediaan }}{\text { Hutang Lancar }}
$$

\subsection{Teori Debt to Equity Ratio (DER)}

Menurut Darmadji dan Fakhruddin (2012:158), "Rasio utang terhadap ekuitas (debt to equity ratioDER) merupakan rasio yang mengukur sejauh mana besarnya utang dapat ditutupi oleh modal sendiri.

Menurut Sartono (2010:120-121), Debt to Equity Ratio menunjukkan proporsi atas penggunaan utang untuk membiayai investasinya. Semakin tinggi rasio ini maka semakin besar risiko yang dihadapi, dan investor akan meminta tingkat keuntungan yang semakin tinggi. Rasio yang tinggi juga menunjukkan proporsi modal sendiri yang rendah untuk membiayai aktiva.

Menurut Sartono (2010:248-249) faktor-faktor yang mempengaruhi struktur modal antara lain sebagai berikut: 
1. Tingkat penjualan, perusahaan dengan penjualan yang relatif stabil berarti memiliki aliran kas yang relatif stabil pula, maka dapat menggunakan utang lebih besar daripada perusahaan dengan penjualan yang tidak stabil.

2. Struktur aktiva, perusahaan yang memiliki aktiva tetap dalam jumlah besar dapat menggunakan utang dalam jumlah besar. Hal ini disebabkan karena dari skalanya perusahaan besar akan lebih mudah mendapatkan akses ke sumber dana dibandingkan dengan perusahaan kecil.

3. Tingkat pertumbuhan perusahaan, semakin cepat pertumbuhan perusahaan maka semakin besar kebutuhan dana untuk pembiayaan ekspansi.

4. Profitabilitas periode sebelumnya merupakan faktor penting dalam menentukan struktur modal. Dengan laba ditahan yang besar, perusahaan akan lebih senang menggunakan laba ditahan sebelum menggunakan utang atau menerbitkan saham baru.

5. Variabilitas laba dan perlindungan pajak, perusahaan dengan variabilitas laba yang kecil akan memiliki kemampuan yang lebih besar untuk menanggung beban tetap yang berasal dari utang.

6. Skal perusahaan, perusahaan besar yang sudah mapan akan lebih mudah memperoleh laba di pasar modal dibanding dengan perusahaan kecil.

7. Kondisi intern perusahaan dan ekonomi makro, perusahaan perlu melihat saat yang tepat untuk menjual saham dan obligasi.

Menurut Darmadji (2012:158) rumus perhitungannya adalah :

$$
\mathrm{DER}=\frac{\text { Total utang }}{\text { Ekuitas }}
$$

\subsection{Teori Net Profit Margin (NPM)}

Menurut Wardiyah (2017:143), "merupakan rasio yang digunakan untuk mengukur laba bersih setelah pajak lalu dibandingkan dengan volume penjualan”.

Menurut Jumingan (2014:161) Dalam laporan laba rugi, jumlah laba usaha dalam perhitungan Net Profit Margin memberikan gambaran yang penting karena menunjukkan tingkat penjualan (keberhasilan kegiatan pembelian, produksi, dan penjualan).

Menurut Jumingan (2014:165), faktor yang mempengaruhi perubahan laba bersih (net income) adalah:

1. Naik turunnya jumlah unit yang dijual dan harga jual per unit.

2. Naik turunnya harga pokok penjualan. Perubahan harga pokok penjualan dipengaruhi oleh jumlah unit yang dibeli atu diproduksi atau dijual dan harga pembelian per unit atau harga pokok per unit.

3. Naik turunnya biaya usaha yang dipengaruhi oleh jumlah unit yang dijual, variasi jumlah unit yang dijual, variasi dalam tingkat harga dan efisiensi operasi persahaan.

4. Naik turunnya pos penghasilan atau biaya non-operasional yang dipengaruhi oleh variasi jumlah unit yang dijual, variasi dalam tingkat harga dan peruba-han kebijaksanaan dalam pemberian atau penerimaan discount.

5. Naik turunnya pajak perseroan yang dipengaruhi oleh besar kecilnya laba

Laba yang diperoleh atau tinggi rendahnya tarif pajak.

6. Adanya perubahan dalam metode akuntansi.

Menurut Sujarweni (2017:65) Rasio ini dapat dihitung dengan rumus:

$$
\mathbf{N P M}=\frac{\text { Laba Setelah Pajak }}{\text { Penjualan }}
$$

\subsection{Penelitian Terdahulu}

Hasdi Suryadi (2017), Penelitian yang dilakukan dengan judul "Analisis Pengaruh ROI, DTA, QR, TATO, PER Terhadap Harga Saham Perusahaan Batubara Di BEI" memberikan hasil penelitian yaitu: Secara simultan dan parsial Quick Ratio berpengaruh positif. Tetapi Return on Investmen, Debt toTotal assets, Total asset Turnover dan Price Earning Ratio secara parsial tidak berpengaruh Positif dan signifikan terhadap harga saham pada perusahaan batubara di BEI.

Aditya Pratama dan Teguh Erawati (2014), Penelitian yang dilakukan dengan judul "Pengaruh Current Ratio, Debt To Equity Ratio, Return On Equity, Net Profit Margin dan Earning Per Share Terhadap Harga Saham Pada Perusahaan Manufaktur yang Terdaftar di Bursa Efek Indonesia Periode 2008-2011" memberikan hasil penelitian yaitu: Secara parsial Ratio berpengaruh positif dan signifikan terhadap harga saham yaitu Current Ratio, Debt to Equity Ratio dan Earning Per Share. Sedangkan secara simultan dari 
kelima variabel memiliki pengaruh signifikan pada perusahaan manufaktur yang terdaftar di Bursa Efek Indonesia periode 2008-2011.

Rescayana Putri Utami (2012), Penelitian yang dilakukan dengan judul "Pengaruh Dividen Per Share, Return On Equity dan Net Profit Margin Terhadap Harga Saham Perusahaan Industri Manufaktur yang tercatat di Bursa Efek Indonesia Periode 2006-2010" memberikan hasil penelitian yaitu: baik secara parsial maupun secara simultan Dividend Per Share, Return on Equity, dan Net Profit Margin berpengaruh positif dan signifikan terhadap harga saham pada perusahaan industri manufaktur yang tercatat di Bursa Efek Indonesia periode 2006-2010.

\subsection{Teori Pengaruh Quick ratio Terhadap Harga Saham}

Menurut Brigham (2010:150), menyebutkan bahwa harga jika rasio likuiditas, manajemen asset, manajemen hutang dan profitabilitas semuanya terlihat baik dan jika kondisi ini berjalan terus menerus secara stabil maka rasio nilai pasar juga akan semakin tinggi, harga saham kemungkinan sesui dengan yang diperkirakan.

\subsection{Teori Pengaruh Debt to Equity Ratio Terhadap Harga Saham}

Menurut Kodrat (2010:283), hubungan antara harga saham seharusnya (nilai intrinsik) dengan Debt to Equity Ratio (DER) adalah positif, yaitu semakin besar rasio antara utang dengan modal, semakin besar harga dari saham.

\subsection{Teori Pengaruh Net Profit Margin Terhadap Harga Saham}

Menurut Jumingan (2014:161), nilai yang dihasilkan dari Net Profit Margin memberi gambaran yang penting karena menunjukkan tingkat keberhasilan penjualan dan pencapaian target laba perusahaan. Net Profit Margin yang tinggi menandakan kemampuan perusahaan menghasilkan laba yang tinggi pada tingkat penjualan tertentu. Net Profit Margin yang rendah menandakan penjualan yang terlalu rendah untuk tingkat biaya tertentu atau biaya yang terlalu tinggi untuk tingkat penjualan tertentu. Secara umum rasio yang rendah menunjukkan ketidakefisienan manajemen dan membuat investor ragu menanamkan dananya yang berakibat pada perusahaan harga saham.

\subsection{Kerangka Konseptual}

Kerangka konseptual dapat digambarkan di bawah ini sebagai berikut :

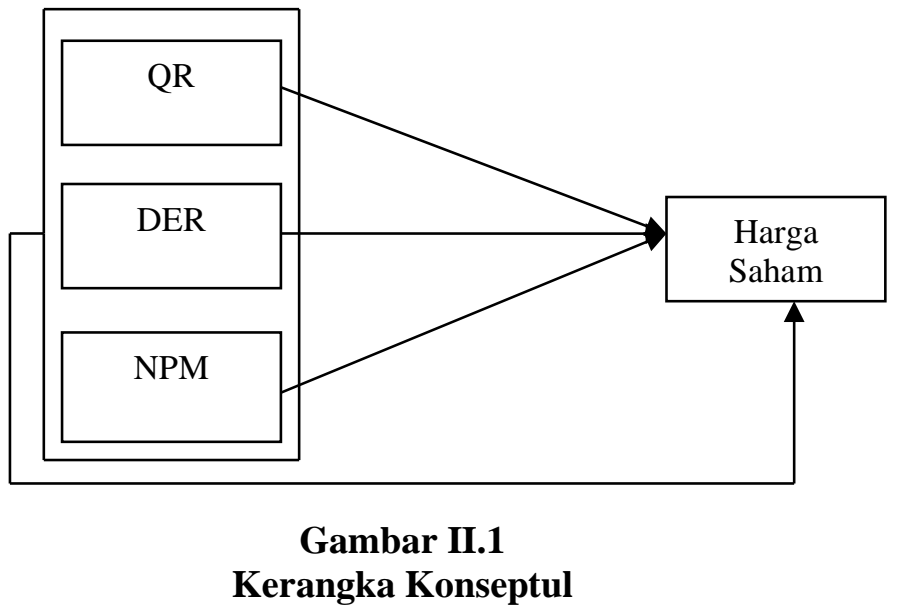

Penelitian ini menyatukan variabel-variabel yang telah ditelusuri oleh peneliti-peneliti sebelumnya untuk menghasilkan dan menjelaskan suatu kesimpulan baru melalui kombinasi variabel independen yang ada dengan variabel dependen yang sama.

\section{METODOLOGI PENELITIAN}

Jenis penelitian yang digunakan dalam penelitian ini adalah penelitian kiantitatif. Penelitian kuantitatif dapat diartikan sebagai metode penelitian yang berlandaskan pada filsavat positivisme, digunakan untuk meneliti pada populasi atau sampel tertentu, pengumpulan data menggunakan instrumen penelitian, analisis data bersifat kuantitatif/statistik, dengan tujuan untuk menguji hipotesis yang telah 
ditetapkan Sugiono (2017:8). Sumber data penelitian dilakukan melalui situs resmi BEI yaitu www.idx.co.id.

Populasi yang digunakan yaitu 50 perusahaan Food and Beverages yang terdaftar di Bursa Efek Indonesia periode 2014-2018. Pengambilan sampel dalam penelitian ini menggunakan purposive sampling method. Yang mana purposive sampling method merupakan penentuan sampel berdasarkan kriteria-kriteria yang ditetapkan.

Kriteria yang ditetapkan:

1. Perusahaan Food and Beverages yang terdaftar di Bursa Efek Indonesia pada periode 2014-2018.

2. Perusahaan Food and Beverages yang mempublikasikan laporan keuangan periode 2014-2018.

3. Perusahaan yang Food and Beverages yang memiliki data harga saham periode 2014-2018.

4. Perusahaan Food and Beverages yang tidak mengalami kerugian pada periode 2014-2018.

Berdasarkan kriteria yang disebutkan di atas, maka diperoleh 10 sampel perusahaan food and beverages.

Model penelitian data ini adalah:

$\mathrm{Y}=\mathrm{a}+\mathrm{b}_{1} \mathrm{X}_{1}+\mathrm{b}_{2} \mathrm{X}_{2}+\mathrm{b}_{3} \mathrm{X}_{3}+\mathrm{e}$

Keterangan :

$\mathrm{Y} \quad=$ Harga Saham

a $\quad=$ Bilangan Konstanta

b1,b2,b3 = Koefisien Regresi

$\mathrm{X} 1=$ Variabel Quick ratio

$\mathrm{X} 2=$ Variabel Debt to equity ratio

$\mathrm{X} 3=$ Variabel Net profit margin

$\mathrm{e} \quad=$ Persentase Kesalahan $(0,05)$

Model analisis data pada penelitian ini adalah menggunakan metode analisis regresi linier berganda. Intuk menguji pengaruh quick rqtio, debt to equity ratio dan net profit margin terhadap harga saham secara parsial digunakan uji-t dan secara simultan digunakan uji-F. Sebelum dilakukan pengujian hipotesis pada regresi linier berganda, terlebih dahulu dilakukan uji asumsi klasik. Pengujian asumsi klasik ini dimaksudkan untuk memastikan bahwa model yang diperoleh benar-benar memenuhiasumsi dasar. Dalam analisis regresi yang dilakukan uji normalitas data, uji multikolinieritas, uji autokolerasi, dan uji heteroskedastisitas.

\section{HASIL PENELITIAN}

\subsection{Statistik Deskriptif}

Menurut Ghozali, Menurut Ghozali, statistik deskriptif memberikan gambaran atau deskripsi suatu data yang dilihat dari nilai rata-rata (mean), standar deviasi, varian, maksimum, minimum, sum, range, kurtosis dan skewness (kemencengan distribusi) dari masing-masing variabel. (2016:19)

Tabel IV.1. Statistik Deskriptif

Descriptive Statistics

\begin{tabular}{|l|r|r|r|r|r|}
\hline & $\mathrm{N}$ & Minimum & Maximum & \multicolumn{1}{c|}{ Mean } & Std. Deviation \\
\hline QR & 50 &, 37 & 3,56 & 1,3689 &, 85748 \\
DER & 50 &, 16 & 3,03 &, 9970 &, 54665 \\
NPM & 50 &, 01 &, 39 &, 0875 &, 08195 \\
Harga Saham & 50 & 63 & 16000 & 4202,58 & 4364,038 \\
Valid N (listwise) & 50 & & & & \\
\hline
\end{tabular}

Sumber : Hasil Pengolahan Data, 2019

1. Quick Ratio (X1) memiliki sampel (n) sebanyak 50, dengan nilai minimum sebesar 0,37 terdapat pada PT. Multi Bintang Indonesia Tbk, tahun 2014. Nilai maksimum sebesar 3,56 terdapat pada PT. Ultra Jaya Milk Industry and Trading Company Tbk, tahun 2016. Nilai rata-rata sebesar 1,3689 dan standar deviasi sebesar 0,85748 .

2. Debt to Equity Ratio (X2) memiliki sampel (n) sebanyak 50, dengan nilai minimum sebesar 0,16 terdapat pada PT. Ultra Jaya Milk Industry and Trading Company Tbk, tahun 2018. Nilai maksimum sebesar 3,03 terdapat pada PT. Multi Bintang Indonesia Tbk, tahun 2014. Nilai rata-rata sebesar 0,9970 dan standar deviasi sebesar 0,54665 .

3. Net Profit margin (X3) memiliki sampel (n) sebanyak 50, dengan nilai minimum 0,01 terdapat pada PT. Budi Starch and Sweetener Tbk, 2014-2015 dan PT. Wilmar Cahaya Indonesia Tbk, tahun 2014. Nilai maksimum sebesar 0,39 terdapat pada PT. Multi Bintang Indonesia Tbk, tahun 2017. Nilai rata-rata sebesar 0,0875 dan standar deviasi sebesar 0,08195. 
4. Harga saham (Y) memiliki sampel (n) sebanyak 50, dengan nilai minimum sebesar 63 terdapat pada PT. Budi starch \& Sweetener Tbk, tahun 2015. Nilai maksimum sebesar 16.000 terdapat pada PT. Multi Bintang Indonesia Tbk, tahun 2018. Nilai rata-rata sebesar 4202,58 dan standar deviasi sebesar 4364,038

\subsection{Hasil Uji Asumsi Klasik}

\subsubsection{Uji Normalitas}

Uji normalitas bertujuan untuk menguji apakah dalam model regresi residual memiliki distribusi normal seperti diketahui bahwa uji t dan uji $\mathrm{F}$ mengasumsikan bahwa nilai residual mengikuti distribusi normal.

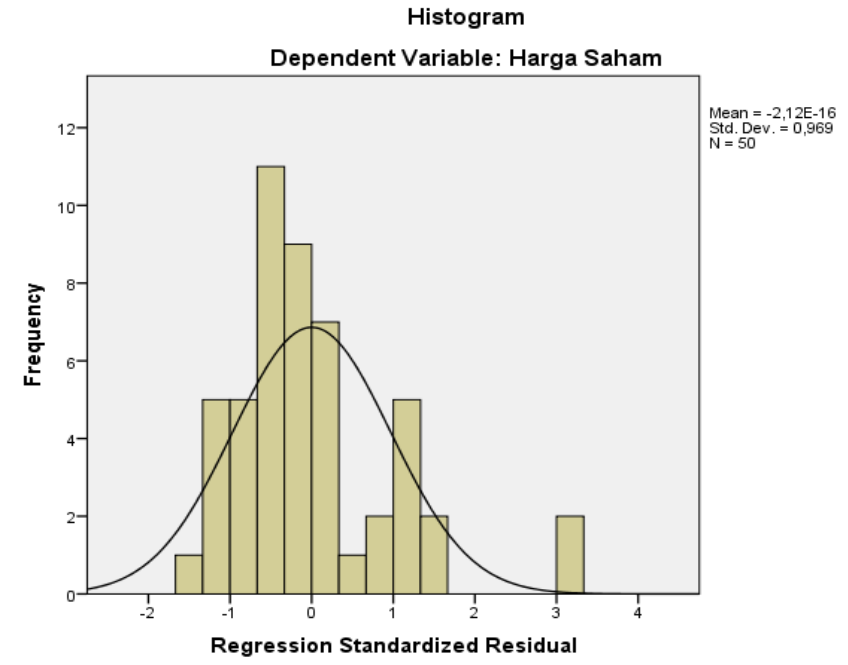

Sumber: Hasil Pengolahan Data, 2019

Gambar IV.1 Normalitas - Histogram (sebelum Transformasi Data)

Berdasarkan tampilan gambar IV.1 di atas terlihat bahwa grafik histogram menunjukkan gambar tidak seperti lonceng sehingga data berdistribusi tidak normal dan tidak memenuhi syarat asumsi normalitas. Maka perlu dilakukan transformasi data dengan LN (logaritma natural) variabel dependen.

Histogram

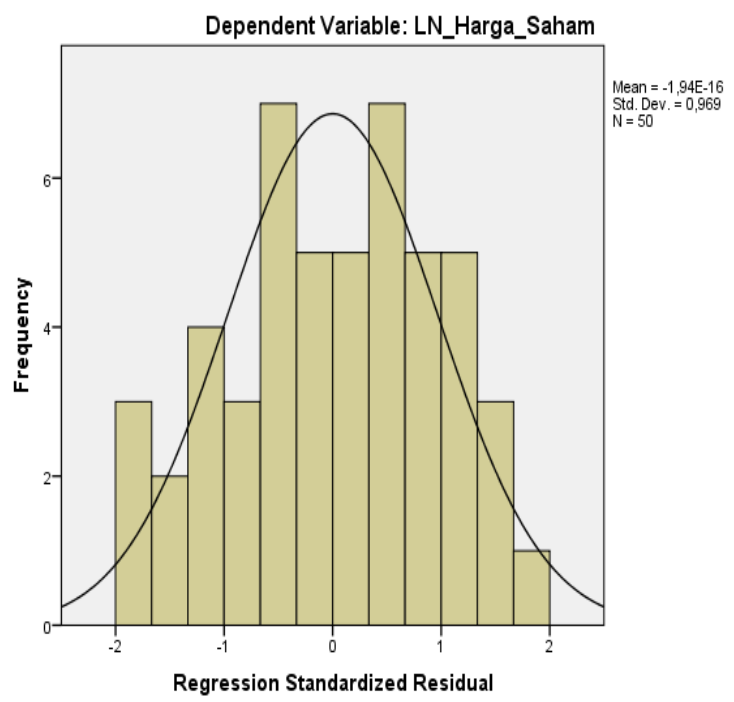

Gambar IV.2 Normalitas - Histogram (Setelah Transformasi Data)

Sumber: Hasil Pengolahan Data 2019

Berdasarkan gambar IV.2 di atas, terlihat gambar garis berbentuk lonceng, tidak melenceng ke kiri maupun ke kanan. Hal ini menunjukkan bahwa data variabel bebas yaitu quick ratio, debt to equity ratio, 
dan net profit margin serta variabel terikat yaitu harga saham terdistribusi normal dan memenuhi asumsi normalitas.

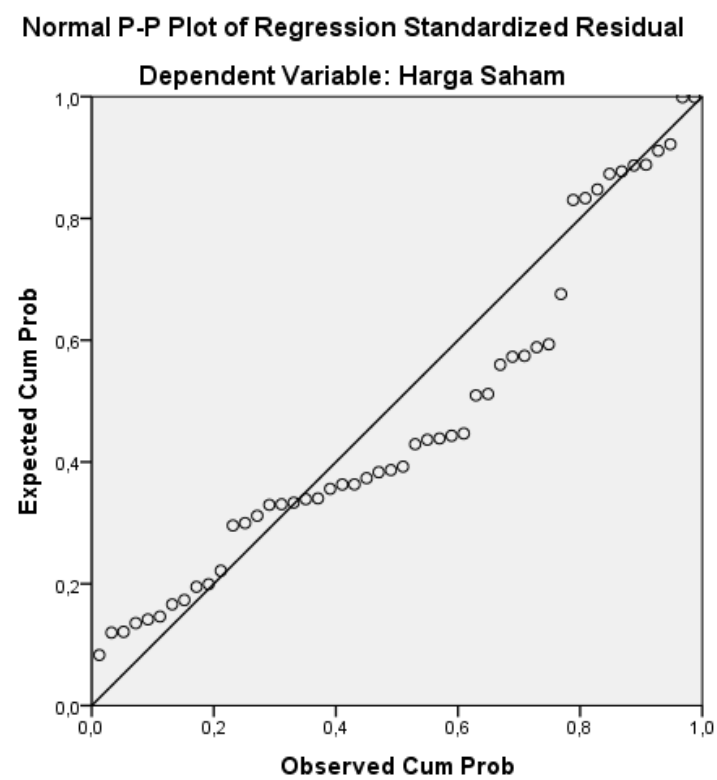

Gambar IV.3 Normalitas -Probability Plot (Sebelum Transformasi)

Sumber: Hasil Pengolahan data, 2019

Grafik PP-Plots sebelum transformasi pada gambar IV.3 menunjukkan data (titik-titik) menyebar disekitar garis diagonal tapi tidak mengikuti garis diagonal karena ada yang terputus. Jadi dari gambar tersebut dapat diambil kesimpulan bahwa residual tersebut tidak berdistribusi secara normal.

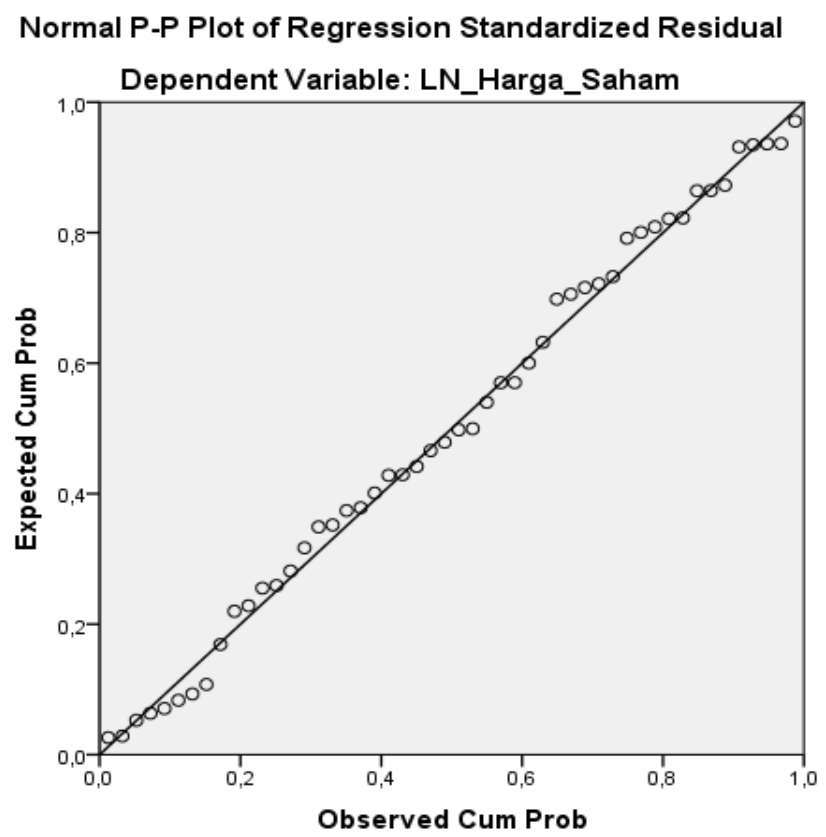

Sumber : Hasil Pengolahan Data SPSS, 2019

\section{Gambar IV.3}

Grafik PP-Plots Setelah Transformasi

Grafik PP-Plots setelah transformasi pada gambar IV.4 menunjukkan data (titik-titik) menyebar disekitar garis diagonal dan mengikuti garis diagonal. Jadi dari gambar tersebut dapat diambil kesimpulan bahwa residual pada model regresi tersebut berdistribusi secara normal. 
Tabel 4.4 : Hasil Uji Normalitas (K-S)

One-Sample Kolmogorov-Smirnov Test

\begin{tabular}{|ll|l|}
\hline & & Unstandardized Residual \\
\hline Normal Parameters & & \\
& Mean & 50 \\
& Std. Deviation & Ab-7 \\
& Absolute &, 175 \\
Most Extreme Differences & Positive &, 175 \\
& Negative &,- 092 \\
Kolmogorov-Smirnov Z & & 1,237 \\
Asymp. Sig. (2-tailed) & &, 094 \\
\hline
\end{tabular}

a. Test distribution is Normal.

b. Calculated from data.

Tabel IV.4 di atas menunjukkan bahwa seluruh data tabel yang digunakan terdistribusi secara normal. Hal ini dapat dilihat dari nilai Kolmogrov-Smirnov (K-S) adalah sebesar 1,237 dengan nilai signifikan lebih besar dari 0,05 yaitu sebesar 0,094 .

\subsubsection{Uji Multikolinieritas}

Multikolinieritas dapat juga dilihat dari nilai Tolerance dan lawannya Variance Inflation Factor (VIF). Kedua ukuran ini menunjukkan setiap variabel bebas manakah yang dijelaskan oleh variabel bebas lainnya. Tolerance mengukur variabelitas variabel bebas yang terpilih yang tidak dapat dijelaskan oleh variabel bebas lainnya.

Tabel 4.3 : Hasil Uji Multikolinieritas Sebelum Transformasi

\begin{tabular}{|c|c|c|}
\hline \\
\hline \multirow{2}{*}{ Model } & \multicolumn{2}{|c|}{ Collinearity Statistics } \\
\hline & Tolerance & VIF \\
\hline (Constant) & & \\
\hline QR & ,467 & 2,142 \\
\hline DER & ,447 & 2,237 \\
\hline NPM & ,904 & 1,106 \\
\hline
\end{tabular}

a. Dependent Variable: Harga Saham

Sumber : Hasil Pengolahan Data, 2019

Tabel IV.3 menunjukkan hasil uji multikolinieritas adalah sebagai berikut :

1. Quick Ratio (X1) dengan nilai tolerance 0,467 > 0,10 dan VIF sebesar 2,142<10.

2. Debt to Equity Ratio (X2) dengan nilai tolerance 0,447 > 0,10 dan VIF sebesar 2,237 < 10 .

3. Net Profit Margin (X3) dengan nilai tolerance 0,904 > 0,10 dan VIF sebesar 1,106 < 10 .

Dari hasil uji di atas dapat disimpulkan bahwa pada model regresi tersebut tidak terdapat masalah multikolinieritas.

Tabel 4.5 : Hasil Uji Multikolinieritas Setelah Transformasi Coefficients $^{\text {a }}$

\begin{tabular}{|c|c|c|c|c|}
\hline \multirow[t]{2}{*}{ Model } & \multicolumn{4}{|c|}{ Collinearity Statistics } \\
\hline & Tolerance & & VIF & \\
\hline (Constant) & & & & \\
\hline QR & & ,467 & & 2,142 \\
\hline DER & & ,447 & & 2,237 \\
\hline NPM & & 904 & & 1,106 \\
\hline
\end{tabular}

a. Dependent Variable: LN_Harga_Saham

Sumber : Hasil Pengolahan Data, 2019

Menunjukkan hasil uji multikolinieritas setelah transformasi adalah sebagai berikut :

1. Quick Ratio (X1) dengan nilai tolerance $0,467>0,10$ dan VIF sebesar 2,142<10. 
2. Debt to Equity Ratio (X2) dengan nilai tolerance 0,447 > 0,10 dan VIF sebesar 2,237 < 10 .

3. Net Profit Margin (X3) dengan nilai tolerance 0,904 > 0,10 dan VIF sebesar $1,106<10$.

Dari hasil uji di atas dapat disimpulkan bahwa pada model regresi tersebut tidak terdapat masalah multikolinieritas.

\subsubsection{Uji Autokolerasi}

Pengujian ini dilakukan untuk mengetahui apakah ada garis autokolerasi antara kesalahan pengganggu pada periode $\mathrm{t}$, dengan kesalahant pada periode t-1 (sebelumnya). Model regresi yang baik adalah tidak ada gejala autokolerasi. Cara yang digunakan untuk mendeteksi adanya autokolerasi adalah dengan uji DurbinWatson. Hasil uji Durbin-Watson sebelum transformasi adalah sebagai berikut :

Tabel 4.6 : Hasil Uji Autokolerasi (DW Test) Sebelum Transformasi

\begin{tabular}{|l|c|r|r|r|r|}
\hline Model & $\mathrm{R}$ & R Square & $\begin{array}{c}\text { Adjusted R } \\
\text { Square }\end{array}$ & $\begin{array}{c}\text { Std. Error of the } \\
\text { Estimate }\end{array}$ & Durbin-Watson \\
\hline 1 &, $757^{\mathrm{a}}$ &, 572 &, 544 & 2945,359 &, 529 \\
\hline
\end{tabular}

a. Predictors: (Constant), NPM, QR, DER

b. Dependent Variable: Harga Saham

Sumber : Hasil Pengolahan Data, 2019

Hasil dari uji autokolerasi dengan menggunakan metode Durbin-Warson (DW Test) sebelum transformasi diperoleh nilai Durbin-Watson (d) sebesar 0,529. Sedangkan dalam tabel DW untuk "k" $=3$, $\mathrm{N}=50$, besar nilai dl (batas bawah) $=1,4206$ dan besar du (batas atas) $=1,6739 ; 4$-du = 2,3261. Dengan melihat kriteria Durbin Watson maka du $<\mathrm{d}<4$-du atau 1,6739 < 0,529 < 2,3261, maka dapat disimpulkan bahwa Durbin-Watson Test terdapat autokolerasi. Hasil uji setelah transformasi adalah sebagai berikut :

\section{Tabel IV.7}

Hasil Uji Autokolerasi (DW Test) Setelah Transformasi

\begin{tabular}{|l|c|r|r|r|r|}
\hline Model & $\mathrm{R}$ & R Square & $\begin{array}{c}\text { Adjusted R } \\
\text { Square }\end{array}$ & $\begin{array}{c}\text { Std. Error of the } \\
\text { Estimate }\end{array}$ & Durbin-Watson \\
\hline 1 &, $712^{\mathrm{a}}$ &, 507 &, 474 & 1,01592 &, 484 \\
\hline
\end{tabular}

a. Predictors: (Constant), NPM, QR, DER

b. Dependent Variable: LN_Harga_Saham

Sumber : Hasil Pengolahan Data, 2019

Hasil dari uji autokolerasi dengan menggunakan metode Durbin-warson (DW Test) setelah transformasi diperoleh nilai Durbin-Watson (d) sebesar 0,484. Dengan melihat kriteria Durbin-watson maka $\mathrm{du}<\mathrm{d}<4$-du atau 1,6739 $<0,484<2.3261$, maka dapat disimpulkan bahwa terdapat autokolerasi pada model regresi linier

\section{IV.2.4 Uji Heteroskedastisitas}

Uji heteroskedastisitas bertujuan untuk mengenal sama atau tidak sama varians dan residual dari observasi satu dengan yang lain. Terjadi homoskedastisitas jika pada scatterplot titik-titik hasil pengolahan data antara Zpred dan Sresid menyebar dibawah maupun diatas titik origin (angka 0) pada sumbu Y dan tidak mempunyai pola yang teratur. Terjadi heteroskedastisitas jika pada scatterplot titik-titiknya mempunyai pola yang teratur baik menyempit, melebar maupun bergelombang-gelombang. 


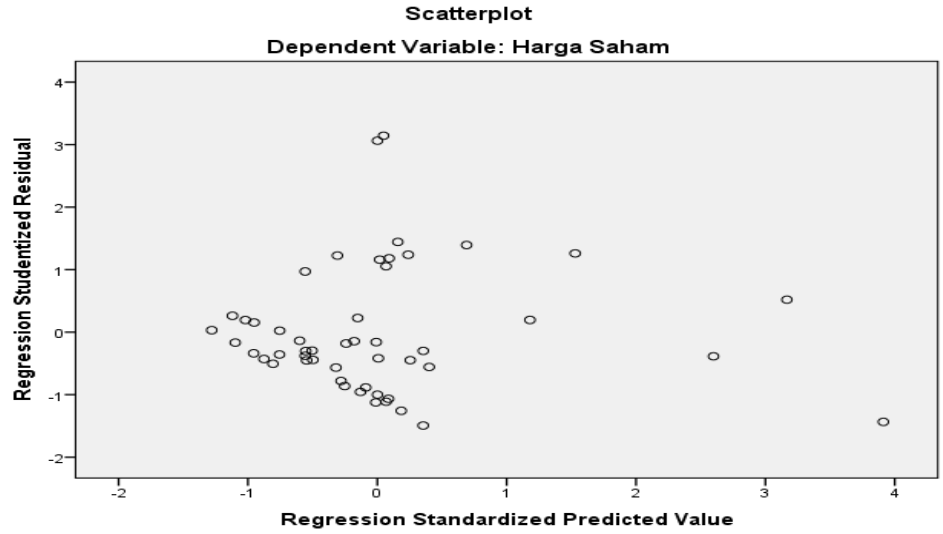

Sumber : Hasil Pengolahan Data, 2019

Gambar 4.5. : Grafik Scatterplot Sebelum Transformasi

Grafik Scatterplot sebelum transformasi pada gambar IV.5 menunjukkan titik-titik tidak menyebar secara acak dan ada yang membentuk pola saling menimpa yang berarti bahwa ada terjadi heteroskedastisitas.

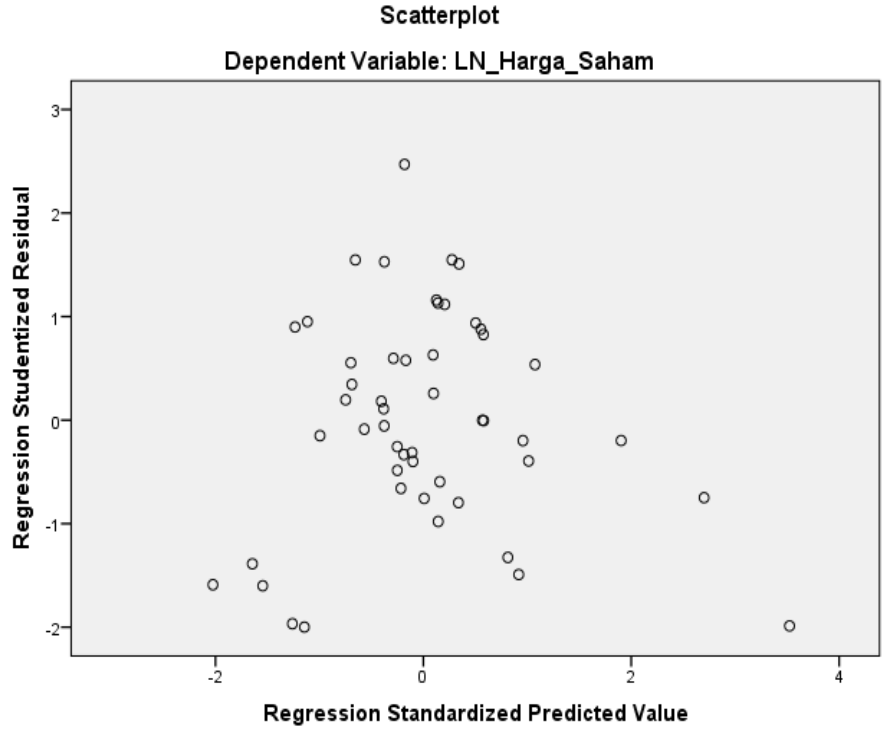

Sumber : Hasil Pengolahan Data, 2019

\section{Gambar 4.6 : Grafik Scatterplot Setelah Transformasi}

Grafik Scatterplot setelah transformasi pada gambar IV.6 menunjukkan titik-titik tersebar secara acak dan tidak membentuk pola tertentu serta tersebar diatas dan dibawah garis 0 yang berarti bahwa tidak terjadi heteroskedastisitas.

Pengujian lain yang dapat dilakukan untuk mengetahui ada atau tidaknya heteroskedastisitas adalah dengan uju glejser. Berikut hasil uji glejser sebelum dan setelah transformasi :

\section{Gambar 4.9}

\section{Hasil Uji Heteroskedastisitas (Uji Glejser) Sebelum Transformasi}

Coefficients ${ }^{\mathbf{a}}$

\begin{tabular}{|l|l|l|l|l|l|}
\hline \multirow{2}{*}{ Model } & \multicolumn{2}{|l|}{ Unstandardized Coefficients } & $\begin{array}{l}\text { Standardized } \\
\text { Coefficients }\end{array}$ & \multirow{2}{*}{ Sig. } \\
\cline { 2 - 4 } & $\mathrm{B}$ & Std. Error & Beta & \\
\hline (Constant) & 4304,719 & 1942,178 & & 2,216 &, 032 \\
QR & $-1385,432$ & 718,225 &,- 272 & $-1,929$ &, 060
\end{tabular}




\begin{tabular}{|l|l|l|l|l|l|} 
DER & $-1870,054$ & 1151,155 &,- 234 & $-1,625$ &, 111 \\
NPM & 41828,519 & 5400,759 &, 785 & 7,745 &, 000 \\
\hline
\end{tabular}

a. Dependent Variable: Harga Saham

Sumber : Hasil Pengolahan Data, 2019

Tabel IV.9 di atas menunjukkan bahwa variabel-variabel independen yaitu Quick Ratio (QR) memiliki nilai signifikan 0,060, Debt to Equity Ratio (DER) memiliki nilai signifikan 0,111, Net Profit Margin (NPM) nemiliki nilai signifikan 0,000. Hasil ini menunjukkan bahwa model regresi terdapat heteroskedastisitas karena nilai signifikan variabel independen ada yang dibawah 0,05.

Gambar 4.10: Hasil Uji Heteroskedastisitas (Uji Glejser) Setelah Transformasi Coefficients $^{\mathrm{a}}$

\begin{tabular}{|l|r|r|r|r|r|}
\hline \multirow{2}{*}{ Model } & \multicolumn{2}{|c|}{ Unstandardized Coefficients } & \multicolumn{1}{c|}{$\begin{array}{c}\text { Standardized } \\
\text { Coefficients }\end{array}$} & \multirow{2}{*}{ Sig. } \\
\cline { 2 - 4 } & \multicolumn{1}{|c|}{ B } & Std. Error & Beta & & \\
\hline (Constant) & 8,565 &, 670 & & 12,785 &, 000 \\
QR &,- 440 &, 248 &,- 269 & $-1,777$ &, 082 \\
DER & $-1,384$ &, 397 &,- 540 & $-3,485$ &, 001 \\
NPM & 12,276 & 1,863 &, 718 & 6,590 &, 000 \\
\hline
\end{tabular}

a. Dependent Variable: LN_Harga_Saham

Sumber : Hasil Pengolahan Data, 2019

Tabel IV.10 di atas menunjukkan bahwa variabel-variabel independen yaitu Quick Ratio (QR) memiliki nilai signifikan 0,081, Debt to Equity Ratio (DER) memiliki nilai signifikan 0,001 dan Net Profit Margin (NPM) memiliki nilai signifikan 0,000. Hal ini menunjukkan bahwa model regresi terdapat heteroskedastisitas karena nilai signifikan variabel independen ada yang dibawah 0,05 .

Hasil uji glejser sebelum dan sesudah transformasi menunjukkan pada model regresi terdapat heteroskedastisitas. Untuk itu dilakukan pengujian dengan uji lain yaitu Uji Spearman's Rho. Hasil Uji Spearman's Rho dapat dilihat pada tabel IV.11 berikut ini :

Tabel 4.11 : Hasil Uji Heteroskedastisitas (Uji Spearman's Rho Correlations

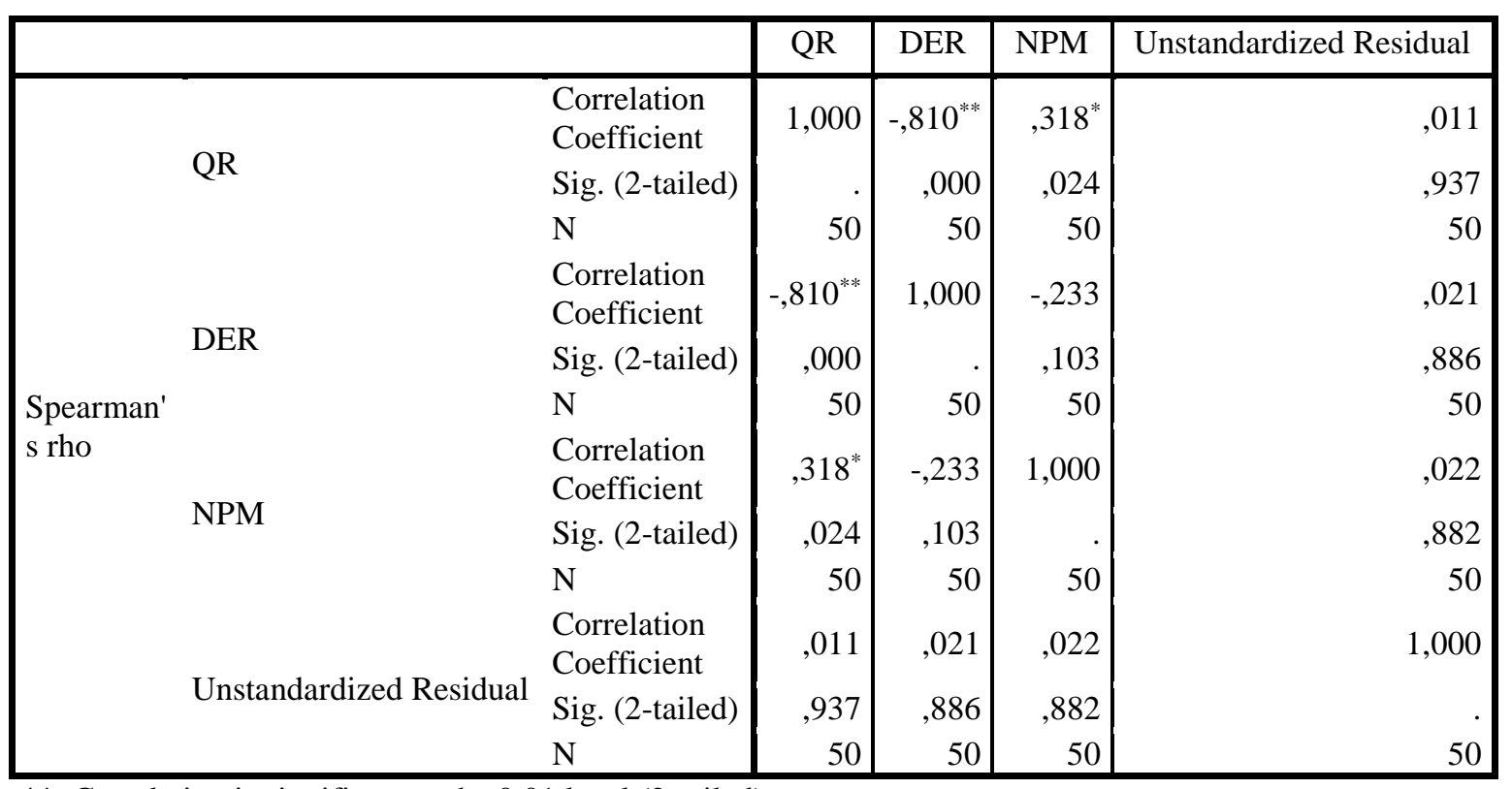

**. Correlation is significant at the 0.01 level (2-tailed).

*. Correlation is significant at the 0.05 level (2-tailed).

Sumber : Hasil Pengolahan Data, 2019 
Hasil pengujian dengan Uji Spearman's Rho menunjukkan bahwa variabel-variabel independen yaitu Quick Ratio (QR) memiliki nilai signifikan 0,937, Debt to Equity Ratio (DER) memiliki nilai signifikan 0,886 dan Net Profit Margin (NPM) memiliki nilai signifikan 0,882. Hal ini menunjukkan bahwa pada model regresi tidak terdapat heteroskedastisitas karena nilai signifikan semua variabel independen diatas 0,05 .

\subsection{Hasil Analisis Data Penelitian}

Setelah melakukan pengujian dengan uji asumsi klasik, maka akan dilakukan pengujian statistik model regresi untuk melihat pengaruh antara variabel bebas dengan variabel terikat baik secara parsial atau individual maupun secara bersama-sama ataupun simultan.

\subsubsection{Model Penelitian}

Analisis linier berganda digunakan untuk memprediksi perubahan (naik-turunya) variabel dependen yang dijelaskan/dihubungkan oleh dua atau lebih variabel independen sebagai faktor prediktor yang dimanipulasi dan untuk mengetahui ada tidaknya pengaruh antara variabel independen terhadap variabel dependen.

Tabel. 4.12: Hasil Pengujian Regresi Linier Berganda Coefficients $^{\text {a }}$

\begin{tabular}{|c|c|c|c|c|c|c|}
\hline \multirow{2}{*}{\multicolumn{2}{|c|}{ Model }} & \multicolumn{2}{|c|}{ Unstandardized Coefficients } & \multirow{2}{*}{$\begin{array}{c}\begin{array}{c}\text { Standardized } \\
\text { Coefficients }\end{array} \\
\text { Beta }\end{array}$} & \multicolumn{2}{|c|}{ Collinearity Statistics } \\
\hline & & $\mathrm{B}$ & Std. Error & & Tolerance & VIF \\
\hline \multirow{4}{*}{1} & (Constant) & 8,565 & 670 & & & \\
\hline & QR &,- 440 & ,248 &,- 269 & ,467 & 2,142 \\
\hline & DER & $-1,384$ & 397 &,- 540 & ,447 & 2,237 \\
\hline & NPM & 12,276 & 1,863 & ,718 & ,904 & 1,106 \\
\hline
\end{tabular}

a. Dependent Variable: LN_Harga_Saham

Melalui data tabel IV.12 di atas, maka persamaan regresi linier berganda yang terdapat pada penelitian ini adalah :

Harga Saham $=8,565-0,440 \mathrm{QR}-1,384 \mathrm{DER}+12,276 \mathrm{NPM}$

Penjelasan untuk persamaan regresi linier berganda tersebut adalah :

1. Hasil Koefisien regresi memperlihatkan nilai konstanta adalah 8,565 memiliki arti bahwa jika variabel bebas Quick Ratio (QR), Debt to Equity Ratio (DER) dan Net Profit Margin (NPM) nol atau tidak ada, maka variabel terikat hasil penelitian yang dilakukan perusahaan yaitu harga saham sebesar 8,565.

2. Nilai koefisien regresi dari variabel $Q R$ adalah sebesar -0,440 yang berarti setiap kenaikan variabel QR sebesar 1 (satu) kali dengan anggapan variabel bebas lainnya 0 (nol) atau konstan, maka harga saham akan turun sebesar 0,440 .

3. Nilai koefisien regresi dari variabel DER adalah sebesar -1,384 yang berarti setiap kenaikan variabel DER sebesar 1 (satu) kali dengan anggapan variabel bebas lainnya 0 (nol) atau konstan, maka harga saham akan turun sebesar 1,384.

4. Nilai koefisien regresi dari variabel NPM adalah sebesar 12,276 yang berarti setiap kenaikan variabel NPM sebesar 1 (satu) kali dengan anggapan variabel bebas lainnya 0 (nol) atau konstan, maka harga saham akan naik sebesar 12,276.

\subsubsection{Koefisien Determinasi Hipotesis}

Uji koefisien determinasi dilakukan untuk mengukur seberapa besar kemampuan varian dari variabel bebas dapat menjelaskan variabel terkait secara simultan. Berikut tabel hasil uji koefisien determinasi hipotesis :

Tabel 4.13

Hasil Pengujian Koefisien Determinasi $\left(\mathbf{R}^{2}\right)$ Model Summary ${ }^{\mathrm{b}}$

\begin{tabular}{|l|l|l|l|l|l|}
\hline Model & $\mathrm{R}$ & $\mathrm{R}$ Square & Adjusted R Square & $\begin{array}{l}\text { Std. Error of the } \\
\text { Estimate }\end{array}$ & Durbin-Watson \\
\hline 1 &, $712^{\mathrm{a}}$ &, 507 &, 474 & 1,01592 &, 484 \\
\hline
\end{tabular}

a. Predictors: (Constant), NPM, QR, DER 
b. Dependent Variable: LN_Harga_Saham Sumber : Hasil Pengolahan Data, 2018

Nilai $R$ Square pada tabel IV.13 adalah 0,507. Nilai Adjusted $R$ Square adalah 0,474 atau sama dengan 47,4\% artinya kemampuan variabel bebas QR, DER dan NPM dalam menjelaskan variasi variabel terikat yaitu harga saham adalah sebesar 47,4\% sedangkan 52,6\% dijelaskan oleh variabel-variabel lain yang tidak diteliti dalam penelitian ini.

\subsubsection{Pengujian Hipotesis Secara Simultan (Uji F)}

Uji simultan (Uji F) digunakan untuk menguji apakah variabel bebas secara simultan atau bersamasama mempengaruhi variabel terikat. Hasil uji simultan (uji F) dapat dilihat pada tabel IV.14 berikut ini :

Tabel IV.14: Hasil Uji Simultan (Uji F)

ANOVA ${ }^{\mathrm{a}}$

\begin{tabular}{|l|r|r|r|r|r|}
\hline Model & Sum of Squares & Df & Mean Square & F & Sig. \\
\hline \multirow{2}{*}{ Regression } & 48,732 & 3 & 16,244 & 15,739 &, $000^{\mathrm{b}}$ \\
Residual & 47,477 & 46 & 1,032 & & \\
Total & 96,209 & 49 & & & \\
\hline
\end{tabular}

a. Dependent Variable: LN_Harga_Saham

b. Predictors: (Constant), NPM, QR, DER

Sumber : Hasil Pengolahan Data, 2019

Pada penelitian ini diketahui jumlah sampel (n) adalah 50 dan jumlah keseluruhan variabel (k) adalah 4, sehingga diperoleh :

1. $\mathrm{df}_{1}($ pembilang $)=\mathrm{k}-1=4-1=3$

2. $\mathrm{df}_{2}$ (penyebut) $=\mathrm{n}-\mathrm{k}=50-4=46$

Berdasarkan hasil uji simultan (uji F) pada tabel IV.14 diatas, maka diperoleh nilai $\mathrm{F}_{\text {hitung }}$ adalah sebesar 15,739 dengan signifikan 0,000. Hasil $F_{\text {tabel }}$ adalah 1.67866. Dengan demikian, nilai $F_{\text {hitung }}>F_{\text {tabel }}$ $(21,856>1.67866)$ dan signifikan lebih kecil dari $0,05(0,000<0,05)$ yang artinya $\mathrm{H}_{0}$ diterima. Jadi, dapat disimpulkan bahwa Quick Ratio (QR), Debt to Equity Ratio (DER) dan Net Profit Margin (NPM) secara simultan berpengaruh positif dan signifikan terhadap harga saham pada perusahaan Food and Beverages yang terdaftar di Bursa Efek Indonesia periode 2014-2018.

\subsubsection{Pengujian Hipotesis Secara Parsial (Uji t)}

Uji parsial (Uji t) bertujuan untuk mengetahui apakah terdapat pengaruh variabel bebas terhadap variabel terikat secara individual. Berikut tabel yang disajikan mengenai hasil uji t :

Tabel 4.15: Hasil Uji Parsial (Uji t)

Coefficients $^{\mathrm{a}}$

\begin{tabular}{|c|c|c|c|c|c|}
\hline \multirow[t]{2}{*}{ Model } & \multicolumn{2}{|c|}{ Unstandardized Coefficients } & \multirow{2}{*}{$\begin{array}{c}\text { Standardized } \\
\text { Coefficients }\end{array}$} & \multirow[t]{2}{*}{$\mathrm{t}$} & \multirow[t]{2}{*}{ Sig. } \\
\hline & $\mathrm{B}$ & Std. Error & & & \\
\hline (Constant) & 8,565 & 670 & & 12,785 &, 000 \\
\hline QR &,- 440 & ,248 &,- 269 & $-1,777$ & 082 \\
\hline DER & $-1,384$ & 397 &,- 540 & $-3,485$ & ,001 \\
\hline NPM & 12,276 & 1,863 & ,718 & 6,590 &, 000 \\
\hline
\end{tabular}

a. Dependent Variable: LN_Harga_Saham

Berdasarkan tabel IV.15 diatas menunjukkan bahwa nilai $t_{\text {tabel }}$ untuk signifikan 0,05 pada 2 arah dan pada derajat kebebasan $\mathrm{n}-\mathrm{k}-1=50-3-1=46$ adalah sebesar 2,01290. Dengan demikian hasil uji $\mathrm{t}$ dapat dijelaskan sebagai berikut :

1. Pengaruh quick ratio $(\mathrm{X} 1)$ terhadap harga saham $(\mathrm{Y})$ diperoleh $\mathrm{t}_{\text {hitung }}$ sebesar $-1,777$ dan $\mathrm{t}_{\text {tabel }}$ sebesar 2,01290 yang hasilnya $\mathrm{t}_{\text {hitung }}<\mathrm{t}_{\text {tabel }}$ dan nilai signifikan sebesar 0,082 dengan tingkat keseluruhan 0,05 yang hasilnya $0.082>0,05$ maka maka $\mathrm{H}_{0}$ ditolak dan $\mathrm{H}_{\mathrm{a}}$ diterima berarti secara parsial quick ratio 
berpengaruh negatif dan signifikan terhadap harga saham pada perusahaan Food and Beverages yang terdaftar di bursa Efek Indonesia periode 2014-2018.

2. Pengaruh debt to equity ratio $\left(\mathrm{X}_{2}\right)$ terhadap harga saham $(\mathrm{Y})$ diperoleh $\mathrm{t}_{\text {hitung }}$ sebesar $-3,485$ dan $\mathrm{t}_{\text {tabel }}$ sebesar 2,01290 yang hasilnya $\mathrm{t}_{\text {hitung }}<\mathrm{t}_{\text {tabel }}$ dan nilai signifikan sebesar 0,001 dengan tingkat keseluruhan 0,05 yang hasilnya $0,001<0,05$ maka $\mathrm{H}_{0}$ ditolak dan $\mathrm{H}_{\mathrm{a}}$ diterima berarti secara parsial debt to equity ratio berpengaruh negatif dan signifikan terhadap harga saham pada perusahaan Food and Beverages yang terdaftar di bursa Efek Indonesia periode 2014-2018.

3. Pengaruh net profit margin $\left(\mathrm{X}_{3}\right)$ terhadap harga saham $(\mathrm{Y})$ diperoleh $\mathrm{t}_{\text {hitung }}$ sebesar 6,590 dan $\mathrm{t}_{\text {tabel }}$ sebesar 2,01290 yang hasilnya $t_{\text {hitung }}>t_{\text {tabel }}$ dan nilai signifikan sebesar 0,000 dengan tingkat keseluruhan 0,05 yang hasilnya $0,000<0,05$ maka $\mathrm{H}_{0}$ ditolak dan $\mathrm{H}_{\mathrm{a}}$ diterima berarti secara parsial net profit margin berpengaruh positif dan signifikan terhadap harga saham pada perusahaan Food and Beverages yang terdaftar di bursa Efek Indonesia periode 2014-2018.

\section{KESIMPULAN}

1. Hasil pengujian secara parsial membuktikan bahwa variabel $Q R$ berpengaruh signifikan terhadap harga saham. Hal ini dapat dilihat dari hasil pengujian hipotesis yang nilai signifikansinya lebih besar dari 0,05 yang berarti hipotesis ditolak.

2. Hasil pengujian secara parsial membuktikan bahwa variabel DER berpengaruh negatif dan signifikan terhadap harga saham. Hal ini dapat dilihat dari hasil pengujian hipotesis yang nilai signifikansinya lebih besar dari 0,05 yang berarti hipotesis ditolak.

3. Hasil pengujian secara parsial membuktikan bahwa variabel NPM berpengaruh positif dan signifikan terhadap harga saham. Hal ini dapat dilihat dari hasil pengujian hipotesis yang nilai signifikansinya lebih kecil dari 0,05 yang berarti hipotesis diterima.

4. Hasil penelitian ini juga membuktikan bahwa DER, NPM dan Ukuran perusahaan secara bersamasama berpengaruh signifikan terhadap harga saham karena mempunyai tingkat signifikansi lebih kecil dari 0,05 (5\%), yang berarti hipotesis diterima.

\section{DAFTAR PUSTAKA}

Brigham \& Houston. 2010. Dasar-Dasar Manajemen Keuangan. Cetakan Pertama. Jakarta: Salemba Empat.

Darmadji, Tjiptono \& Hendy, M. Fakhruddin. 2012. Pasar Modal Di Indonesia Pendekatan Tanya Jawab. Cetakan Kedua, Jakarta: Salemba Empat.

Fahmi, Irham. 2014. Pengantar manajemen Keuangan. Cetakan Kelima. Bandung.

Ghozali, Imam. 2016. Aplikasi Analisis Multivariate Dengan Program IBM SPSS 21, Ed 7. Jakarta : Universitas Diponegoro.

Hani, Syafrida. 2015. Teknik Analisis Laporan Keuangan. Cetakan Pertama. Medan: UMSU PRESS

Hutami, Putri, Rescyana. 2012. Pengaruh Dividen Per Share, Return On Equity dan Net Profit Margin Terhadap Harga Saham Perusahaan Industri Manufaktur yang tercatat di Bursa Efek Indonesia Periode 2006-2010. Volume. 1 Nomor. 1 Fakultas Ekonomi Universitas Negeri Yogyakarta.

Harmono. 2015. Manajemen Kuangan. Cetakan keempat. Jakarta: Penerbit PT Bumi Aksara.

Jumingan. 2014. Analisis Laporan Keuangan. Cetakan kelima. Jakarta: Penerbit PT Bumi Aksara.

Kasmir. 2010. Pengantar Manajemen Keuangan. Cetakan kelima. Penerbit: Prenadamedia Group. Jakarta -------. 2012. Analisis Laporan keuangan. Cetakan kelima. Jakarta: PT Raja Grafindo Persada.

Kodrat, Sukardi, David \& Kurniawan, Indonanjaya. 2010. Manajemen Investasi Pendekatan Teknikal dan Fundamental Untuk Analisis Saham. Cetakan Pertama. Yogyakarta: Graha Ilmu.

Munawir. 2014. Analisa Laporan Keuangan. Ed. Cetakan ketiga belas. Liberty Yogyakarta.

Murhadi, R. Werner. 2015. Analisis Laporan Keuangan. Jakarta: Penerbit Salemba Empat.

Pratama, Aditya. 2014. Pengaruh Current Ratio, Debt To Equity Ratio, Return On Equity, Net Profit Margin dan Earning Per Share Terhadap Harga Saham Pada Perusahaan Manufaktur Yang Terdaftar di Bursa Efek Indonesia Periode 2008-2011. Jurnal Akuntansi. Vol.2 No.1 Juni 2014

Prihadi, Toto. 2012. Praktis Memahami Laporan Keuangan Sesuai IFRS \& PSAK. Cetakan Kedua. Jakarta: Ppm.

Priyatno. (2017). Panduan Praktis Olah Data menggunakan SPSS.

Ryanto, Bambang. 2010. Dasar-Dasar Pembelajaran Perusahaan. Cetakan keenam, Penerbit: BPFE. Yogyakarta

Sanusi, Anwar. 2014. Metodologi Penelitian Bisnis. Cetakan Kelima. Penerbit: Salemba Empat. Jakarta Selatan.

Sartono, Agus. 2012. Manajemen Keuangan dan Teori Aplikasi. Cetakan Keenam. Yogyakarta: BPFE. 
Siahaan, Beslyder, Dhani. 2017. Pengaruh PBV, DER dan ROE Terhadap Harga Saham Perusahaan Manufaktur yang terdaftar Di Bursa Efek Indonesia. E-Jurnal Administrasi Bisnis Vol. 5 No. 32017.

Sugiyono. 2017. Metode Penelitian Kuantitatif, Kualitatif dan R\&D. Cetakan Ke-20. Bandung: CV Alfabeta.

Sujarweni, V. Wiratna. 2014. Metodologi Penelitian. Cetakan Pertama, Penerbit: Pustakabarupress. Yogyakarta.

2017. Analisis Laporan Keuangan. Cetakan Pertama. Yogyakarta

Suryadi, Hasdi. 2017. Analisis Pengaruh ROI, Dta, QR, TATO, PER Terhadap Harga Saham Perusahaan Batubara Di BEI. Vol.3 No. 1 Maret 2017 ASMI Nusantara Banjarmasin

Tandelilin, Eduardus. 2014. Portofolio dan Investasi Teori dan Aplikasi. Cetakan Kelima. Yogyakarta Wardiyah, Lasmi, Mia. 2017. Analisis Laporan Keuangan. Cetakan Ke-1. Bandung: CV Pustaka Setia.

-----. 2017. Manajemen Pasar Uang \& Pasar Modal. Cetakan ke-1. Bandung: CV Pustaka Setia.

Sumber Internet:

http://www.idx.co.id

http://finance.yahoo.com 